\title{
A Cognitive Analysis of Poems in A Dream of Red Mansions from the Perspective of Image Schema
}

\author{
Yunyi Xia ${ }^{1}$, Yuemin Wang ${ }^{2}$ \\ ${ }^{1}$ School of Foreign Languages and Cultures, Nanjing Normal University, Nanjing, China \\ ${ }^{2}$ Department of Foreign Languages, University of Chinese Academy of Sciences, Beijing, China \\ Correspondence: Yuemin Wang, Department of Foreign Languages, University of Chinese Academy of Sciences, \\ Yuquan Road 19\#, Beijing, China.
}

\author{
Received: May 27, $2021 \quad$ Accepted: June 19, $2021 \quad$ Online Published: June 22, 2021 \\ doi:10.5430/elr.v10n3p1 URL: https://doi.org/10.5430/elr.v10n3p1
}

\begin{abstract}
This paper adopts a cognitive perspective in the analysis of various image schemas in the novel A Dream of Red Mansions, one of the most influential classical masterpieces in Chinese literature. Two poems from the novel are interpreted from the perspective of link schema, container schema, up-down schema, part-whole schema, and source-path-goal schema, to reveal the personalities, values and life philosophies of the two female protagonists. The contrast between the pessimism and melancholy of Daiyu and the optimism and aspiration of Baochai demonstrates the author's understanding of that time and society, especially the status and fate of females. The analysis illustrates that image schemas, which involves bodily experience and metaphorical projection from concrete to abstract domains, can surpass language boundaries, reveal emotions and themes, and shed light on cross-cultural studies of literature.
\end{abstract}

Keywords: image schema, cognitive poetics, Chinese poetry, A Dream of Red Mansions

\section{Introduction}

Cognitive linguistics studies language based on our experience of the world and the way we perceive and conceptualize it (Ungerer \& Schmid, 1996). With the development of cognitive linguistics, more and more scholars attempted to study poetry from cognitive perspectives. Since the appearance of cognitive poetics, new approaches have entered the field of studies of poetry, based on both literary texts and cognitive linguistic strategies (Freeman, 1997; Brône \& Vandaele, 2009). Studies combining poetry and cognition are concerned with aspects including figure and ground, image, cognitive grammar, mental space, conceptual metaphor, etc. With these theories, we comprehend abstract notions through embodied experiences. Schemas inherent in a certain culture can also determine our interpretation of the literary texts.

There are some linguists who tried to interpret poems with the theory of image schema. For example, Freeman (2002) used it to compare the poems of Robert Frost and Emily Dickinson, which showed its advantages in understating the poetic language in English. However, few have tried from this perspective on Chinese poetry, which has a long and splendid history of more than 30 centuries. Chinese poets have various ways in expressing themes and emotions. Exploring the image schemas will facilitate a better understanding not only of the poems, but also of the poets and the cultural background.

Therefore, this paper will analyze two poems in Cao Xueqin's classical work A Dream of Red Mansions from the approach of image schema, seeking to show how image schema can help to produce a vivid and reliable interpretation of ancient Chinese poetry.

\section{A Brief Review of Image Schema}

\subsection{Definition}

Image schema, also called image schemata, is one of the most important issues in cognitive linguistics. It was introduced by Lakoff and Johnson (1980) as the basis of metaphorical mapping from source domain to target domain. Johnson (1987: xiv) further defined it as "a recurring, dynamic pattern of our perceptual interaction and motor programs that gives coherence and structure to our experience". He argues that image schemata are gestalt structures, 
consisting of parts standing in relations and organized into unified wholes, and that they make it possible for us to "experience, understand and reason" about our world. Similarly, Gibbs \& Colston (1995: 349) defined image schemas as "dynamic analog representations of spatial relations and movements in space", and Oakley (2004) viewed the concept as "a condensed re-description of perceptual experience for the purpose of mapping spatial structure onto conceptual structure". Though these definitions differ in expression, they reflect similar characteristics of image schema.

\subsection{Characteristics}

According to Lakoff (1987), the significance of image schemas is that they provide particularly important evidence for the claim that abstract reason is a matter of two things: (a) reason based on bodily experience, and (b) metaphorical projections from concrete to abstract domains. This indicates that image schemas are recurring structures within our cognitive process, which emerge from our everyday interaction with the world. Through repeated bodily experience in the world consisting of events and relations, we acquire cognitive patterns or schema of spatial relationship, such as UP-DOWN, FRONT-BACK, IN-OUT, NEAR-FAR, etc.

Moreover, image schemata are not concrete images but abstract and inherent cognitive structures. They function as "identifying patterns in an indefinitely large numbers of experience, perceptions, and image formations for objects or events that are similarly structured in the relevant ways" (Johnson, 1987). They cover a wide range of experiential structures that are pervasive in experiences, and can be metaphorically elaborated to provide for our understanding of more abstract domains (Lakoff, 1987). Holmqvist (1993) gave a more detailed and vivid description: image schema "could be said to be that part of a picture which remains when all the structure is removed from the picture, except for that which belongs to a single morpheme, a sentence or a piece of text in a linguistic description of a picture... that which remains is a highly fluid image, specified in some aspects...but completely unspecified in other". From this perspective, image schema is an important conceptual structure in cognitive semantics as it provides a connection between bodily experience and higher cognitive domains such as language (Mark \& Johnson, 1987).

\subsection{Major Types}

Image schemas can be metaphorically extended from the physical to the nonphysical experience in abstract domains. They firstly emerged as a structure of bodily interactions, and then figuratively developed as more abstract cognitive structures. Lakoff (1987) discussed the possibility that many areas of experience are metaphorically structured by means of a small number of image schemas. The major types of mapping are as follows:

\section{1) Container Schema}

The physical foundation is that the human body is a container. The structural elements include INTERIOR, BOUNDARY and EXTRIOR. Emotional states or language expressions are often understood as objects in containers.

e.g.: the content of the book; empty words; fall in love; out of trouble; on the surface of the words, etc.

2) Part-Whole Schema

The physical foundation is that human bodies are whole beings consisting of various parts. The components include PART, WHOLE and STRUCUTRE. Social organizations or unities are understood as wholes with parts.

e.g.: This couple broke up last year, but they came together two months ago.

3) Link Schema

The embodied experience is that the primary link of human being is the umbilical cord. The structural elements include two entities and a link. Social communications or interpersonal relations are often understood in terms of links.

e.g.: closely connected; break the ties, the fetter of slavery, etc.

4) Up-Down Schema

The physical foundation is that human beings stand upright with head up and feet down, and do most activities in that orientation. This pair can be mapped to abstract concepts such as quantities, emotions, physical conditions, social status, etc., often with "up" on the positive side and "down" the negative.

e.g.: the number rises; fall ill; he is really low these days, etc.

5) Source-Path-Goal Schema

The physical foundation is the movement of an object from one point to anther. The structural elements include a 
starting point, a destination, a path connecting the two and the direction toward the destination. Purposes are often understood in terms of destinations, and the process of pursuing a purpose as the path from the starting point to the destination.

\section{e.g.: his way to success; a feasible approach; obstacles in the way}

There are many other schemas, such as Center-Periphery Schema, Front-Back Schema, Linear Order Schema, Force Schema etc., which will not be elaborated in this study.

\section{Analysis and Discussion}

A Dream of Red Mansions is one of the four great classic novels in the history of Chinese literature, written in the mid-eighteenth century. Few Chinese novels have enjoyed such extensive and enduring appreciation, as well as great popularity in the academic field. Based on his own experience in a family in decline, the author Cao Xueqin was able to depict a panorama of the splendid yet decadent feudal society in his time. The major and most engaging theme of the masterpiece is the tragic love story between Jia Baoyu and Lin Daiyu, who, under the oppression from the aristocratic family and the tease of destiny, could not be together. Baoyu was forced to marry Xue Baochai, a girl favored by the elders in the family, while Daiyu died of disease and a broken heart. The author showed deep sympathy for the young couple and tried his best to portray different characters through their appearances, conversations, as well as psychological activities, with about 100 poems throughout the novel. In this paper, the widely accepted translation of two poems (see the Appendix) are selected and interpreted with different types of image schemas. Through comparison of poems of different characters, their personality and life philosophies that the author tried to convey will also be revealed.

\section{1 "The Song of Burying Flowers" by Daiyu}

This poem is the most important representation of Daiyu that the author endeavored to depict. At the sight of flowers falling from the trees, Daiyu, the sentimental orphan girl, pours out her sorrow and complaint about her own life experience. In the verse consisting of 26 lines, the rich imagination, gloomy images, and strong sentiment reveal her grief and indignation in the grim reality after realizing the unavailability of ideal love and happiness, as well as her unwillingness to yield to oppression and humiliation in the struggle of life and love. Three major types of image schemas adopted are identified and discussed here.

\section{1) Link Schema}

The Link Schema often represents the relationship between people and the society. In Daiyu's eyes, the life of flower resembles the destiny of a girl; once the flowers fade, their connection with the tree or branch will be broken: "when spring draws to a close and flowers fall, this is the season when beauty must ebb and fade". Hence images with cut link like "the faded red, the scent that has been", "the blossoms fly across the sky", "the gossamer floats", "the willow fluff wafts", "peach and plum blossom drift away" are abundant in the poem. In the novel, Daiyu lost her parents at an early age, and Baoyu was the only one in the world who sincerely cared for her. It is natural since Daiyu compared herself to the flowers, or rather, the author compared females to flowers: the state of these flowers drifting away stand for the isolated and wandering state of the heroine, indicating the tragic fate of her and other female characters in the story.

\section{2) Container Schema}

The Container Schema often represents emotional states or characteristics within a person. In this poem, the Container Schema can be found from three perspectives. Firstly, Daiyu's heart was immersed in such profound melancholy that she didn't know how to release it, as is clearly expressed in "no relief from anxiety her poor heart knows". Secondly, she lived in Jia's family with "the lodge ... locked and still", and "a green lamp lights the wall; cold rain pelts the casement". These embodied experiences produce a feeling of imprisonment, which in turn reinforces the feeling of isolation and loneliness. She didn't have the freedom to live as she wished, not to mention to be together with her love. The images of locked doors, closed walls, and windows serve as boundaries that restrained her in the manipulation of those with power, or of the overall external environment in that society. Thirdly, Daiyu was a girl with high self-esteem. Though born in a society that she was extremely out of tune with, she kept her innocence and integrity. Even dead, she would rather be buried in "a fragrant burial mound", as she did to the flowers: "shroud the fair petals in silk, with clean earth for their outer attire". The container should be fragrant and clean so as to match with her soul.

\section{3) Source-Path-Goal Schema}

The Source-Path-Goal Schema often represents the process of approaching a destination, such as a purpose or the 
end of life. In this poem, it is clear that Daiyu longed for a far-away wonderland, that "I long to take wing and fly, with the flowers to earth's uttermost bound". The projection of the destination is a pure place, in contrast with the filthy environment where she lived in reality, which is implied in the line "pure you came and pure shall you go, not sinking into some foul ditch or mire". The Source-Path-Goal Schema embodied here expresses Daiyu's yearning for relief from this world to one in her imagination. Besides, another line can also be interpreted by this image schema: "suddenly it (spring) comes and suddenly goes, its arrival unheralded, noiseless its departing". Here, spring can be understood as the happiness brought by love. She cherished the mutual understanding and affection between her and Baoyu, but their love was killed by external forces. Like the season of spring, she could see neither the starting point nor the destination of their relationship. Only the intangible process remained in her memory.

\section{2 "On Catkin" by Baochai}

In the novel, this poem was also written in late spring, when catkin began to fly. The young people in the big family held a contest in which everyone wrote a poem about catkin, and the one by Baochai was voted as the best. The first stanza portrays the scenery of catkin flying in the spring breeze, while the second stanza expresses Baochai's aspiration of going up to higher positions. The emotions revealed in this poem form a dramatic contrast with those in Daiyu's poem. There are also three major types of image schema in discussion here.

\section{1) Up-Down Schema}

The Up-Down Schema can represent the rise or fall of one's status. Baochai voiced her aspiration for success in the line "lend me strength, good wind, to soar up to the azure sky at last". She was different from Daiyu in that she could better fit into the big upper-class family as well as the overall social environment and holds main-stream values of the time. Daiyu wished to get away from that world while Baochai wanted to ascend in it; Daiyu looked beyond while she looked up. The different perspectives lead to different fates. However, one element in the different schematic structures is common, that both depend on the force of the wind. In other words, the control of life was not in their hands. Even Baochai, who was so optimistic and ambitious, could not become the master of her own destiny.

\section{2) Part-Whole Schema}

The Part-Whole Schema often represents the splitting or assembling of certain unities. In the line "constant to the ten thousand boughs, whether together or parted I keep trust", Baochai showed her open-mindedness towards the state of the community. On the surface, she was referring to the catkins which came together or parted with each other under the control of the wind; deep down, she had the vision to accept whatever life brought to her and people around her and would not change her original aspiration. Daiyu was sensitive towards changes in relationships, while Baochai was broader-minded. This also explains her calmness and composedness when the whole family declined later.

\section{3) Source-Path-Goal Schema}

Similar to Daiyu's poem, this poem also adopts the Source-Path-Goal Schema. On the one hand, Baochai questioned Daiyu's pessimism about flowing with the control of destiny in asking "I have never followed the flowing stream, Why then should I abandon myself to the dust". Though she could accept the hardness or misfortunes in life, she was determined to do something. Again, she had a different goal from Daiyu - "the azure sky", and thus chose a different path. Eventually, due to various factors in the time, she could not go along this path towards her goal and was obliged to "follow the flowing stream". Nevertheless, the contrast of dream and reality enhances the idea that the author tried to convey: smart and ambitious as Baochai was, she still couldn't resist the arrangement of fortune in a society where females remained in an inferior status.

\section{Conclusion}

Based on a brief overview of image schema by its definition, characteristics, and major types, two most representative poems in A Dream of Red Mansions are analyzed from a cognitive perspective. The analysis reveals the embodied structures in the poems that associate concrete images and abstract relations. From the comparison of the major image schemas in the two poems, we can see the differences between the two characters, including their personality, values and aspirations. The image schemas, which involve shared bodily experiences, can provide a new perspective in understanding the traditional Chinese poetry and promote cross-cultural studies of literature.

\section{References}

Brône, G., \& Vandaele, J. (eds.). (2009). Cognitive poetics: Goals, gains and gaps. Berlin: Walter de Gruyter. https://doi.org/10.1515/9783110213379

Gibbs, R. W., \& Colston, H. L. (1995). The cognitive psychological reality of image schemas and their transformations. Cognitive Linguistics, 6(4), 347-278. https://doi.org/10.1515/cogl.1995.6.4.347 
Holmqvist, K. (1993). Implementing Cognitive Semantics. Lund: Lund University Cognitive Studies.

Lakoff, G. (1987). Women, Fire, and Dangerous Things: What Categories Reveal about the Mind. Chicago: The University of Chicago Press. https://doi.org/10.7208/chicago/9780226471013.001.0001

Lakoff, G., \& Johnson, M. (1980). Metaphors We Live by. Chicago: The University of Chicago Press.

Mark, J. (1987). The Body in the Mind. Chicago: The University of Chicago Press.

Oakley, T. (2004). Image Schema. In Dirk G. \& H. Cuyckens (eds.) To Appear in the Handbook of Cognitive Linguistics. Oxford: Oxford University Press.

Ungerer, F., \& Schmid, H. J. (1996). An Introduction to Cognitive Linguistics. London: Longman Press.

Yang, H. Y., \& Yang, G. (trans.). (1978). A Dream of Red Mansions. Peking: Foreign Language Press. 
Appendix: translation of the two poems (Yang \& Yang, 1978)

\section{The song of burying flowers}

As blossoms fade and fly across the sky, Who pities the faded red, the scent that has been? Softly the gossamer floats over spring pavilions, Gently the willow fluff wafts to the embroidered screen. A girl in her chamber mourns the passing of spring,

No relief from anxiety her poor heart knows;

Hoe in hand she steps through her portal,

Loath to tread on the blossom as she comes and goes.

Willows and elms, fresh and verdant,

Care not if peach and plum blossom drift away;

Next year the peach and plum blossom will bloom again,

But her chamber may stand empty on that day.

By the third month the scented nests are built,

But the swallows on the beam are heartless all;

Next year, though once again you may peck the buds,

From the beam of an empty room your nest will fall.

Each year for three hundred and sixty days

The cutting wind and biting frost contend.

How long can beauty flower fresh and fair?

In a single day wind can whirl it to its end.

Fallen, the brightest blooms are hard to find;

With aching heart their grave-digger comes now

Alone, her hoe in hand, her secret tears

Falling like drops of blood on each bare bough.

Dusk falls and the cuckoo is silent;

Her hoe brought back, the lodge is locked and still;

A green lamp lights the wall as sleep enfolds her,

Cold rain pelts the casement and her quilt is chill.

What causes my two-fold anguish?

Love for spring and resentment of spring;

For suddenly it comes and suddenly goes,

Its arrival unheralded, noiseless its departing.

Last night from the courtyard floated a sad song-

Was it the soul of blossom, the soul of birds,

Hard to detain, the soul of blossom or birds?

For blossoms have no assurance, birds no words.

I long to take wing and fly

With the flowers to earth's uttermost bound;

And yet at earth's uttermost bound

Where can a fragrant burial mound be found?

Better shroud the fair petals in silk

With clean earth for their outer attire;

For pure you came and pure shall you go,

Not sinking into some foul ditch or mire.

Now you are dead I come to bury you;

None has divined the day when I shall die;

Men laugh at my folly in burying fallen flowers,

But who will bury me when dead I lie?

See, when spring draws to a close and flowers fall,

This is the season when beauty must ebb and fade;

The day that spring takes wing and beauty fades 
Who will care for the fallen blossom or dead maid?

\section{On catkin}

Dancing at ease in spring before white jade halls,

Swirling gracefully in the spring breeze;

While whirling all around me,

Are butterflies and bees;

I have never followed the flowing stream,

Why then should I abandon myself to the dust?

Constant to ten thousand boughs,

Whether together or parted I keep trust;

Do not jeer at me as rootless,

But lend me strength, good wind,

To soar up to the azure sky at last!

\section{Copyrights}

Copyright for this article is retained by the author(s), with first publication rights granted to the journal.

This is an open-access article distributed under the terms and conditions of the Creative Commons Attribution license (http://creativecommons.org/licenses/by/4.0/). 